\title{
Current investigations into the genotoxicity of zinc oxide and silica nanoparticles in mammalian models in vitro and in vivo: carcinogenic/ genotoxic potential, relevant mechanisms and biomarkers, artifacts, and limitations
}

This article was published in the following Dove Press journal:

International Journal of Nanomedicine

15 December 2014

Number of times this article has been viewed

\author{
Jee Young Kwon ${ }^{1, *}$ \\ Preeyaporn Koedrith ${ }^{2, *}$ \\ Young Rok Seo' \\ 'Department of Life Science, \\ Institute of Environmental Medicine, \\ Dongguk University, Seoul, Republic \\ of Korea; ${ }^{2}$ Faculty of Environment \\ and Resource Studies, Mahidol \\ University, Phuttamonthon District, \\ NakhonPathom, Thailand \\ *These authors contributed equally \\ to this work and should be considered \\ as co-first authors
}

Correspondence: Young Rok Seo Room 408-I Hyehwa-building, Dongguk University, 30 Pildong-ro I-gil, Jung-gu, Seoul 100-7I5, Republic of Korea

$\mathrm{Tel}+82222603321$

Fax +82222901392

Email seoyr@dongguk.edu

\begin{abstract}
Engineered nanoparticles (NPs) are widely used in many sectors, such as food, medicine, military, and sport, but their unique characteristics may cause deleterious health effects. Close attention is being paid to metal NP genotoxicity; however, NP genotoxic/carcinogenic effects and the underlying mechanisms remain to be elucidated. In this review, we address some metal and metal oxide NPs of interest and current genotoxicity tests in vitro and in vivo. Metal NPs can cause DNA damage such as chromosomal aberrations, DNA strand breaks, oxidative DNA damage, and mutations. We also discuss several parameters that may affect genotoxic response, including physicochemical properties, widely used assays/end point tests, and experimental conditions. Although potential biomarkers of nanogenotoxicity or carcinogenicity are suggested, inconsistent findings in the literature render results inconclusive due to a variety of factors. Advantages and limitations related to different methods for investigating genotoxicity are described, and future directions and recommendations for better understanding genotoxic potential are addressed.
\end{abstract}

Keywords: carcinogenicity, exposure assessment, genotoxicity, nanoparticles, risk evaluation

\section{Introduction}

The rapidly growing nanotechnology industry will have significant economic and scientific impact in areas such as aerospace engineering, nanoelectronics, environmental remediation, and health care. ${ }^{1}$ The design and development of novel engineered nanoparticles (NPs) are important to the industry due to beneficial physicochemical features that have led to over $800 \mathrm{NP}$-containing consumer products. ${ }^{2}$ Hence, human exposure is high and continues to increase dramatically.

Due to their small size and great surface area coupled with physicochemical characteristics such as metal contaminations and charged surfaces, NPs may exhibit unpredictable genotoxic properties. Indirect DNA damage may be caused by induction of oxidative stress and inflammatory responses. Small NPs may cross cellular membranes and access the nucleus, where direct DNA interaction may result in damage. If NPs accumulate within a cell but do not readily gain access to the nucleus, direct DNA contact is possible during mitosis, when the nuclear membrane breaks down and gives rise to opportunity for DNA aberrations. 
Occupational exposure of workers in the semiconductor, automotive, and aerospace industries is a primary concern, but NPs are also widely used in numerous cosmetics (such as lipstick, sunscreen, and antiaging creams), as well as medical sources (such as debris from dental prosthesis and orthopedic implants). ${ }^{3-5}$ There is promise that NPs could be administered as diagnostic aids, drug carriers, and therapeutic treatments for patients. ${ }^{6,7}$ With current and near-future exposure scenarios, workers in nanotechnology industries have the highest levels of chronic exposure to NPs, patients receiving NP-based treatments would have high-to-medium exposures over a limited duration, and consumers would likely have low, chronic exposures.

Among a variety of NPs, zinc oxide ( $\mathrm{ZnO})$ and silica NPs are in the most attractive positions for advanced nanotechnology industries and their potential applications, especially biomedical and pharmaceutical fields. They are also continuously directed for the advent of novel devices with multifunctionalities and multiple purposes, providing great benefits to human health. In particular, mesoporous $\mathrm{ZnO}$ and silica NPs have striking characteristics for application as drug carriers. They exhibit high surface area and porous interiors serving as reservoirs of drug molecules. The pore size and surrounding environment can influence the storage of various drugs of interest, whereas the size and shape of NPs can affect cellular uptake. ${ }^{8}$ For example, mesoporous silica has been successfully utilized for delivery of ibuprofen into the pores via hydrogen bond interaction between ibuprofen and the silanol functional groups in the pore wall. ${ }^{9}$ Moreover, highly mesoporous spherical three-dimensional $\mathrm{ZnO}$ nanoassemblies have been accomplished for loading doxorubicin hydrochloride as a model drug. ${ }^{10}$ Both silica and ZnO NPs are generally regarded as essentially nontoxic and nonirritant beyond oral and topical pharmaceutical applications. In clinical use, individuals who may be more vulnerable to NP toxicity due to their pre-existing medical conditions thus require the examination of genotoxic potential and the underlying mechanism of action.

\section{Key characteristics of nanoparticles}

Due to large surface-area-to-volume ratio, NPs exhibit distinct physicochemical (eg, optical, magnetic, and electrical) and catalytic properties, rendering higher numbers of atoms binding on particle surfaces than their bulk counterparts. ${ }^{11,12}$ These characteristics of NPs promote their diffusion, reactivity, hardness, dimensionality, and suspension ability.

Usually, optical features of NPs are attributed to their ability to confine electrons to a very tiny size and to generate quantum effects. These optical absorption properties are related to their structure and shape. For instance, the yellow color of silver suspension in nanoform becomes a blue color in clustered form. Likewise, the color of gold NPs changes from blue to green to magenta, corresponding to their size and shape.

The suspension formation of NPs is also unique due to the great interaction force between their surface and suspension media, enabling density differences to be overcome. ${ }^{13}$ In contrast, interactions of bulk material often result in either sinking or floating in liquid media. In aqueous media, NPs are dispersed due to electrostatic and steric repulsion of their surface charge (positive/negative) ${ }^{14}$ Brownian motion and collision also have a crucial role in dispersion. As surface charges of NPs skew toward zero value, repulsive forces between NPs become decreased, eventually leading to their sedimentation by gravitational forces. The agglomeration process involves adhesion toward particles, mostly due to van der Waals forces resulting from their large surface-area-tovolume ratio at nanoscale (Figure 1). ${ }^{15}$ Due to agglomeration/ aggregation, the physicochemical properties (eg, surface charge, size, size distribution, surface-area-to-volume ratio, surface reactivity) of NPs become altered, leading to mediation of their bioavailability and toxicities..$^{16,17}$

In addition, diffusion of NPs is unique because it regulates their behavior in the surrounding environment. Indeed, particle diffusion coefficient is negatively proportional to the particle diameter. The smaller the particle size, the higher the diffusional forces, presenting the behavior tendency of gas or vapor. ${ }^{18,19}$ Thus, NPs with high diffusion coefficient display high mobility and consequently mix quickly in an aerosol. After their release in the environment, atmospheric diffusion rapidly promotes the migration of NPs, leading to them quickly traveling a long distance from the source and increasing detrimental health risks. ${ }^{20}$

Additionally, other predominant properties of NPs are quantum confinement in semiconductors (eg, triple quantum dot silicon-based semiconductor, transition metal-doped ferromagnetic semiconducting silicon nanotubes, and $\mathrm{ZnO}$ semiconductor), ${ }^{21-23}$ surface plasmon resonance in particular metal NPs (eg, doped silicon nanocrystals, $\mathrm{ZnO}$, and copper $\mathrm{NPs}$ ), ${ }^{24,25}$ and superparamagnetism in magnetic materials (eg, multifunctional silica nanocomposites, gadolinium complexes, fluorophores, cell-penetrating peptides, and transition metal-doped ferromagnetic semiconducting silicon nanotubes). ${ }^{22,26,27}$ For instance, ferroelectric materials $(<10 \mathrm{~nm}$ in size) can switch their magnetization direction using room temperature thermal energy, rendering them inappropriate 


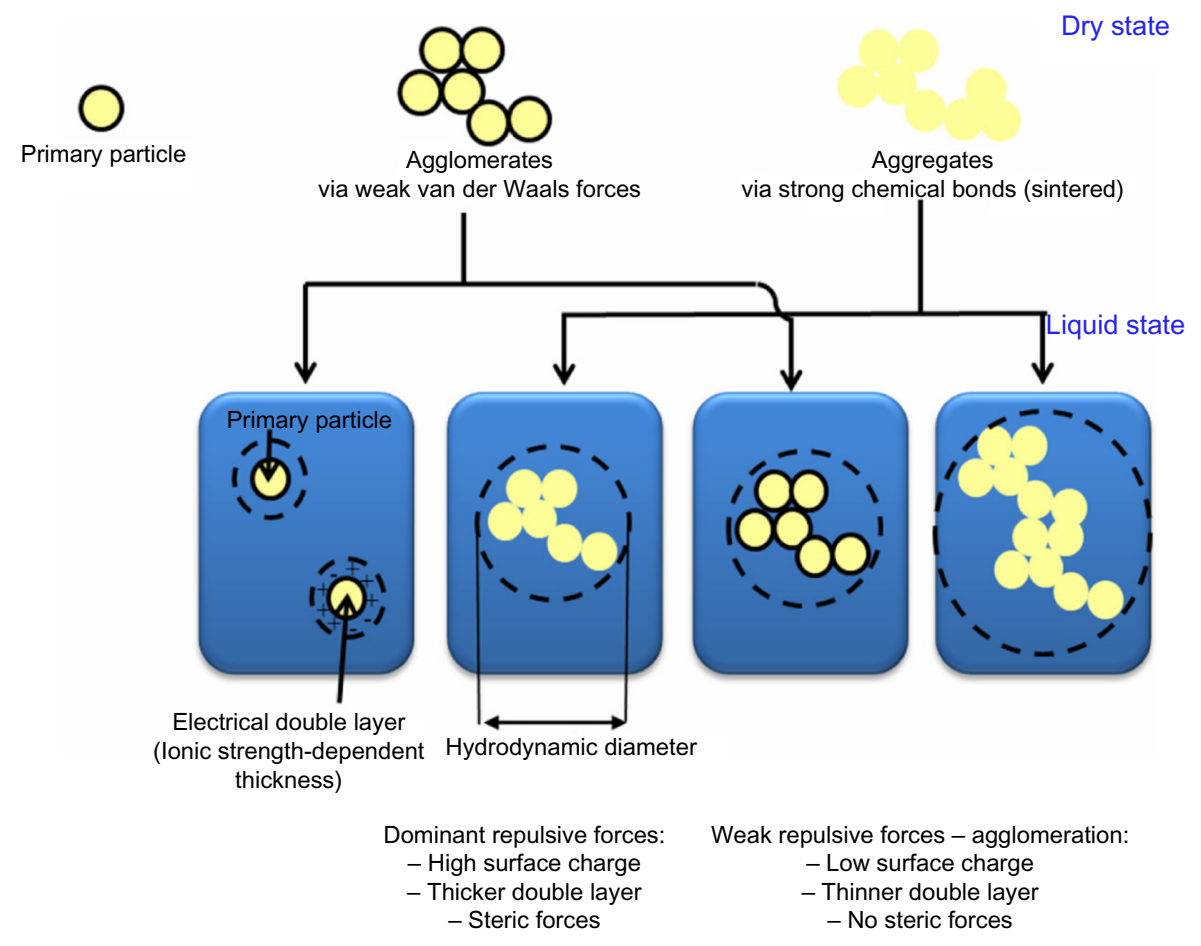

Figure I Various states of nanoparticles in different forms of dry powder and liquid in suspension media.

for memory storage. Copper NPs ( $<50 \mathrm{~nm}$ in size) are also regarded as superior durable materials that do not confer the same malleability and ductility as their bulk counterpart. ${ }^{28}$

Regarding the unique features of NPs, their physicochemical properties should definitely be characterized prior to investigating the impact on human and environmental health. They include size, shape, structure, composition, purity, aggregation/agglomeration (size distribution), particle number, mass concentration, surface area, porosity, roughness, morphology, surface charge and chemistry, crystallinity, dispersity, and solubility. Measurement of primary particle size, hydrodynamic diameter, size distribution, zeta potential (surface charge), dispersity, concentration, and period of time in which agglomeration occurs provide better understanding of NP behavior relative to their cytotoxic and genotoxic responses.

\section{Recent genotoxicological studies of metal oxide nanoparticles in in vitro and in vivo mammalian models \\ Zinc oxide nanoparticles}

$\mathrm{ZnO}$ NPs are used in applications such as cosmetics, paints, drug carriers, and fillings in medical materials. ${ }^{29}$ Also used as ultraviolet (UV) blocking materials, especially for UVA, their high catalytic activity in oxidation and photochemical reactions limits their use as UV blockers..$^{30} \mathrm{ZnO}$ NPs are thought to be nontoxic and biocompatible. ${ }^{31}$ Exposure to $\mathrm{ZnO}$ NPs has been associated with inflammatory responses ${ }^{32}$ and cytotoxicity. ${ }^{33-35}$ Little work regarding the genotoxic potential of $\mathrm{ZnO}$ NPs has been conducted. A previous investigation used Chinese hamster ovary cells to study chromosomal aberrations induced by $\mathrm{ZnO}$ NPs with a mean diameter of $100 \mathrm{~nm}$ promoted by UV light, finding increased clastogenicity under preirradiation and simultaneous irradiation conditions than in the dark. ${ }^{29}$ This study indicates that $\mathrm{ZnO}$ NPs may cause photogenotoxicity, but a lack of information of the physicochemical properties makes the validity of the experiments questionable. Further assessment to fully investigate genotoxicity with a focus on size dependence and physiochemical features is required.

In vivo, the genotoxic potential of $\mathrm{ZnO}$ NPs has been investigated in animal models with systematic administration for 14 consecutive days, ${ }^{36}$ as well as for 90 days. ${ }^{37}$ The exposures increased liver enzyme and oxidative DNA breakage.

Recently, in vitro and in vivo, the mammalian toxicity of $\mathrm{ZnO}$ NPs as well as their toxicokinetics in various types of cells and animal models have been summarized (Table 1)..$^{34,35,38-41}$ In vitro, comet assays and the cytokinesisblocked micronucleus present genotoxicity. Moreover, lung cells with in vitro exposure show cytotoxicity, increased 
Table I Genotoxicity studies of $\mathrm{ZnO}$ and silica nanoparaticles using in vitro and in vivo mammalian models

\begin{tabular}{|c|c|c|c|}
\hline \multirow{2}{*}{$\begin{array}{l}\text { Nanoparticles } \\
\mathrm{ZnO}\end{array}$} & \multicolumn{2}{|c|}{ Toxicological effect } & \multirow{2}{*}{$\begin{array}{l}\text { Reference } \\
\text { Landsiedel et } \mathrm{al}^{63}\end{array}$} \\
\hline & $\begin{array}{l}\text { Genotoxicity } \\
\text { in vivo }\end{array}$ & $\begin{array}{l}\text { Using in vivo micronucleus test, no genotoxic effect was observed in lung cells from rats } \\
\text { exposed to triethozycaprylylsilane-coated } \mathrm{ZnO} \text { by inhalation }\end{array}$ & \\
\hline & & $\begin{array}{l}50 \mathrm{~nm} \mathrm{ZnO} \text { had not induced micronucleus in the animal model at a concentration of up to } \\
5 \mathrm{~g} / \mathrm{kg} \text { body weight }\end{array}$ & Li et $\mathrm{al}^{64}$ \\
\hline & & $60-200 \mathrm{~nm} \mathrm{ZnO}$ did not induce genotoxicity in the in vivo system & $\begin{array}{l}\text { Monteiro-Riviere } \\
\text { et al }{ }^{65}\end{array}$ \\
\hline & Genotoxicity & Genotoxic potential was observed in $\mathrm{ZnO}$ exposed cells by alkaline standard comet assay & Gopalan et al ${ }^{66}$ \\
\hline & in vitro & $\begin{array}{l}\text { Using comet assay, significant DNA damage was induced by } 30 \mathrm{~nm} \mathrm{ZnO} \text { in a } \\
\text { dose-dependent manner }\end{array}$ & Sharma et al ${ }^{38}$ \\
\hline & & $\begin{array}{l}\text { Induction of DNA damage was observed significantly in } 10 \mathrm{~nm} \text { and } 20 \mathrm{~nm} \mathrm{ZnO} \text { exposure of } \\
\text { Caco-2 cells with and without Fpg enzyme }\end{array}$ & Gerloff et al ${ }^{67}$ \\
\hline & & Significant DNA damage was observed in $19.6 \pm 5.8 \mathrm{~nm}$ at $5 \mu \mathrm{g} / \mathrm{mL}$ and $10 \mu \mathrm{g} / \mathrm{mL}$ & Yang et al ${ }^{68}$ \\
\hline & & Water-soluble $\mathrm{ZnO}$ nanoparticles have no mutagenic potential in Ames test & Yoshida et $a^{69}$ \\
\hline & & $\begin{array}{l}\text { Diemthyoxydiphenylsilane/triethoxycaprylylsilane crosspolymer-coated } \mathrm{ZnO} \text { was evaluated } \\
\text { as nongenotoxic substance in Ames test }\end{array}$ & Landsiedel et $\mathrm{a}^{63}$ \\
\hline & & $\begin{array}{l}\text { Genotoxicity was observed by comet assay and micronucleus test in HEp- } 2 \text { cells exposed } \\
\text { to } \mathrm{ZnO}\end{array}$ & Osman et al $7^{70}$ \\
\hline & & $\begin{array}{l}\text { Poly methyl acrylic acid coated } \mathrm{ZnO} \text { induced significantly increased genotoxicity compared } \\
\text { with uncoated } \mathrm{ZnO} \text { measured by micronucleus test in WIL2-NS human lymphoblastoid cells }\end{array}$ & Yin et $\mathrm{al}^{71}$ \\
\hline & & A significant increase in DNA damage was observed in $30 \mathrm{~nm} \mathrm{ZnO}$ exposed cells & Sharma et $\mathrm{al}^{72}$ \\
\hline & & $30 \mathrm{~nm} \mathrm{ZnO} \mathrm{nanoparticles} \mathrm{induced} \mathrm{DNA} \mathrm{damage} \mathrm{in} \mathrm{in} \mathrm{vitro} \mathrm{system}$ & Sharma et $\mathrm{al}^{73}$ \\
\hline & & $\begin{array}{l}\text { DNA damage measuring by comet assay was observed in human nasal mucosa exposed } \\
\text { to } \mathrm{ZnO} \text { repetitively }\end{array}$ & Hackenberg et $\mathrm{al}^{74}$ \\
\hline & $\begin{array}{l}\text { Oxidative } \\
\text { stress }\end{array}$ & $\begin{array}{l}\text { Poly methyl acrylic acid-coated } \mathrm{ZnO} \text { showed decreased cytotoxicity and } \mathrm{ROS} \text { generation } \\
\text { compared with uncoated } \mathrm{ZnO} \text { in WIL2-NS human lymphoblastoid cells }\end{array}$ & Yin et $\mathrm{al}^{75}$ \\
\hline & & $\begin{array}{l}\mathrm{ZnO} \text { induced mitochondrial dysfunction, morphological modification, and apoptosis in } \\
\text { human fetal lung fibroblast }\end{array}$ & Zhang et $\mathrm{al}^{76}$ \\
\hline & & ZnO led to cellular oxidant injury, inflammation, and cell death in in vitro system & Xia et $\mathrm{al}^{77}$ \\
\hline & & Oxidative stress and cytotoxicity were induced by $\mathrm{ZnO}$ in human colon carcinoma cells & De Berardis et $\mathrm{al}^{78}$ \\
\hline & & ZnO induced oxidative DNA damage and ROS-mediated apoptosis in human liver cells & Sharma et $\mathrm{al}^{79}$ \\
\hline & & $\begin{array}{l}\text { Induction of oxidative stress, DNA damage, and apoptosis were observed in a malignant } \\
\text { human skin melanoma cell line exposed to } \mathrm{ZnO}\end{array}$ & Alarifi et al ${ }^{80}$ \\
\hline & & $\mathrm{ZnO}$ induced ROS-mediated cytotoxic effect in rat retinal ganglion cells & Guo et $a^{81}$ \\
\hline \multirow[t]{18}{*}{ Silica } & Genotoxicity & No induction of hypoxanthine phosphoribosyltransferase-encoding gene (HPRT) mutation & Johnston et a ${ }^{82}$ \\
\hline & in vivo & frequency was observed in rats exposed to silica for 13 weeks & \\
\hline & & Inhalation of $37 \mathrm{~nm}$ and $83 \mathrm{~nm} \mathrm{SiO}$, did not induce genotoxicity in rat lung & Sayes et $a^{83}$ \\
\hline & Genotoxicity & A weak induction of micronuclei was observed in V79 cells at highly cytotoxic doses & Liu et $a^{84}$ \\
\hline & in vitro & No mutagenic potential was observed in Ames test with and without metabolic activation & ECETOC, 85 \\
\hline & & Also, no induction of chromosomal aberrations was observed in mammalian cells & $\mathrm{EPA},{ }^{86} \mathrm{OECD}{ }^{87}$ \\
\hline & & $\begin{array}{l}\text { No induction of genotoxicity was detected by comet assay in mouse fibroblasts exposed } \\
\text { to silica }\end{array}$ & Barnes et $\mathrm{a}^{51}$ \\
\hline & & $\begin{array}{l}\text { A very slight DNA damage was observed in silica-exposed primary mouse embryo } \\
\text { fibroblast cells by comet assay }\end{array}$ & Yang et $\mathrm{a}^{68,88}$ \\
\hline & & $\begin{array}{l}\text { No significant induction of genotoxicity was observed in A549 cells exposed to } \\
\text { amorphous silica particles for } 40 \text { hours }\end{array}$ & Gonzalez et $\mathrm{al}^{89}$ \\
\hline & & $\begin{array}{l}\text { Significant increase of micronuclei was induced in mouse fibroblast cells exposed } \\
\text { to } 80 \mathrm{~nm} \text { silica nanoparticles }\end{array}$ & Park et al90,91 \\
\hline & $\begin{array}{l}\text { Oxidative } \\
\text { stress }\end{array}$ & $\begin{array}{l}\mathrm{SiO}_{2} \text { induced cytotoxicity via production of oxidative stress in human embryonic } \\
\text { kidney cells }\end{array}$ & Wang et $\mathrm{a}^{92}$ \\
\hline & & P53 and Bax-mediated apoptosis was induced by $\mathrm{SiO}_{2}$ exposure in human hepatic cell line & Ye et $\mathrm{al}^{93}$ \\
\hline & & P53 and P2I-mediated GI phase arrest was observed in myocardial cells & Ye et $\mathrm{al}^{94}$ \\
\hline & & $\begin{array}{l}\text { Endocytosis-dependent ROS generation and DNA damage was induced by nanosilica } \\
\text { in human keratinocytes }\end{array}$ & Nabeshi et al ${ }^{62}$ \\
\hline & & $\begin{array}{l}20 \mathrm{~nm} \text { silica induced cytotoxic effects via induction of ROS and lipid peroxidation } \\
\text { in kidney cells }\end{array}$ & Passagne et $\mathrm{al}^{61}$ \\
\hline & & $\begin{array}{l}\text { Nanosized silica induced developmental neurotoxicity via production of oxidative stress } \\
\text { in } \mathrm{PCI} 2 \text { cells }\end{array}$ & Wang et al ${ }^{59}$ \\
\hline & & Hepatotoxicity was induced by $\mathrm{SiO}_{2}$ in Kupffer cells & Chen et $\mathrm{a}^{95}$ \\
\hline & & $\mathrm{SiO}_{2}$ led to cutaneous toxicity via $\mathrm{ROS}$ generation & Park et al ${ }^{96}$ \\
\hline
\end{tabular}

Abbreviations: $\mathrm{ROS}$, reactive oxygen species; $\mathrm{SiO}_{2}$, silicon dioxide; $\mathrm{ZnO}$, zinc oxide. 
oxidative stress, decreased mitochondrial membrane potential, and production of interleukin-8. Likely, the ZnO NPs are phagocytosed by macrophages and dissolved in lysosomes. In vivo, the $\mathrm{ZnO} N P s$ exhibit systemic distribution in target organs, including the liver, spleen, lung, kidney, and, in some cases, heart.

The current review focuses on nanocosmetic $\mathrm{ZnO}$ sunscreens that have been thought not to be toxic, irritating, sensitizing, or photosensitizing after topical application. ${ }^{42}$ The toxicity issue has also been examined by the European Commission, where sunscreen preparations containing $\mathrm{ZnO}$ NPs were reviewed. ${ }^{42}$ Current studies have suggested that NPs do not exhibit increased penetration. ${ }^{43,44}$ However, populations with unhealthy skin or wounds still need to be cautious about long-term topical use of nanoscreens.

\section{Silica nanoparticles}

Silica induces inflammatory response via nuclear factor kappa B activation and oxidative stress responses both in vivo and in vitro, ${ }^{32,45,46}$ but cytotoxicity is observed only at high concentrations. ${ }^{47,48}$ Silica NPs have been shown to enter the cell nucleus to potentially bind to the DNA phosphate backbone. ${ }^{49}$ The silica NPs induce the reactive oxygen species (ROS), ${ }^{46}$ especially the hydroxyl radical, a highly reactive molecule that may induce DNA strand breaks and oxidized bases. ${ }^{50}$

Silica NPs have an impact on nuclear integrity, forming intranuclear protein aggregates and resulting in inhibition of replication, transcription, and cell proliferation. ${ }^{49}$ Moreover, decreased replication activity as well as transcriptional activity were found for cells exposed to silica NPs. NPs of size $>200 \mathrm{~nm}$ fail to penetrate the nucleus and do not alter nuclear structure and function or interfere with gene expression. ${ }^{49}$ Nevertheless, there is limited evidence showing the genotoxic potential of silica NPs. ${ }^{48,51} \mathrm{~A}$ micronucleus assay report shows that these NPs do induce chromosomal damage. ${ }^{52}$ To better indicate genotoxic potential, a battery of standardized tests quantifying different types of genetic aberrations are needed to cover all potential forms of inducible DNA damage as a result of exposure to NPs.

Recent work assessing systemic toxicological mechanisms of silica NPs in terms of cytotoxicity, genotoxicity, and phototoxicity has been reviewed and summarized (Table 1). ${ }^{34,35,53-57}$ Based on extensive physicochemical characterization, ecotoxicology, toxicology, safety, and epidemiology data, environmental and health risks seem to be unassociated with these particles if produced or utilized under current hygiene standards and recommendations. Silica
NP interactions with membranes may induce the release of endosomal substance, ROS, cytokines, and chemokines, resulting in inflammatory responses. ${ }^{58-62}$ Silica NP toxicity is likely linked to mechanisms of interaction with outer and inner membranes, signaling responses, and vesicle trafficking pathways, but human health and environmental risks and the mechanisms of toxicity are not fully elucidated.

Taken together, genotoxicological investigations of $\mathrm{ZnO}$ and silica NPs have been carried out using in vitro and in vivo mammalian models, as summarized in Table 1.

\section{Key mechanisms underlying nanoparticle-induced DNA damage}

If NPs are able to enter the body through inhalation, dermal, or oral routes, direct and indirect mechanisms exist to stimulate DNA damage. ${ }^{34,35,97}$ NPs may be able to penetrate into the cell, and subsequently the nucleus, through a number of routes (Figure 2). ${ }^{1}$ If NPs are located within the nucleus, direct interaction with DNA or DNA-associated proteins is possible. Indeed, silica NPs can enter the nucleus, ${ }^{98,99}$ inducing intranuclear protein aggregates and resulting in inhibition of replication, transcription, and cell proliferation. ${ }^{49,100,101}$ Quantum dots have also been shown to penetrate the nucleus via the nuclear pore complexes ${ }^{102}$ and interact with histone proteins.

Genotoxicity may arise through indirect mechanisms where NPs do not physically interact with the DNA molecule but with other cellular components, such as those involved in the cell division process. Other cellular responses may be induced and give rise to genotoxicity, such as oxidative stress induction, inflammatory response, and aberrant signaling responses (Figure 3). ${ }^{1,35,97}$ Moreover, putative mechanisms underlying the detrimental effects of $\mathrm{ZnO}$ and silica NPs are proposed (Figure 4).

\section{Oxidative stress}

Oxidative stress is a redox imbalance within cells as a consequence of increased intracellular ROS and decreased antioxidants. ROS-induced DNA damage is categorized by single- and double-stranded DNA breaks, base modifications (eg, formation of 8-hydroxydeoxyguanosine adducts), and DNA crosslinks, all of which may be implicated to initiate and promote carcinogenesis if unrepaired. ${ }^{103,104}$

The transition metals ions (such as iron [Fe] and zinc) released from certain NPs are capable of converting cellular oxygen metabolic products (such as $\mathrm{H}_{2} \mathrm{O}_{2}$ and superoxide anions) to hydroxyl radicals and to DNA damaging species. $\mathrm{Fe}(\mathrm{II})$ can cause the production of $\mathrm{H}_{2} \mathrm{O}_{2}$ from molecular $\mathrm{O}_{2}$, 


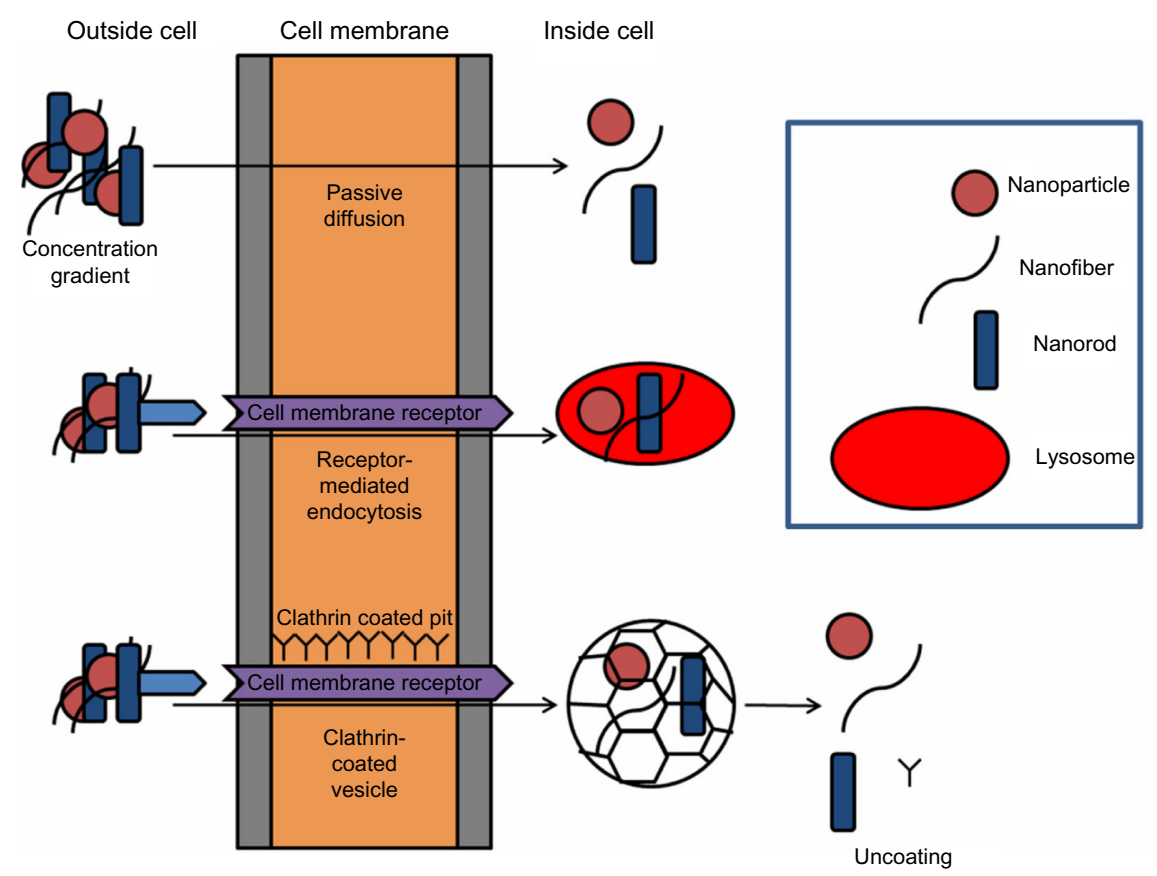

Figure 2 Scheme illustrating possible routes of cellular uptake, including passive diffusion, receptor-related endocytosis, and clarthrin- or caveolae-dependent endocytosis. In brief, nanoparticles are in the correct size and shape. They may dock on membrane receptors, facilitating receptor-mediated endocytosis. Alternatively, clathrin- or caveolaemediated endocytosis may occur, which results in the formation of pits in the region of $120 \mathrm{~nm}$ or up to $80 \mathrm{~nm}$, respectively, which regulates the size of the material they are able to enclose.

which can diffuse through the cellular and nuclear membranes to react with DNA-bound Fe and lead to radical production, crosslinking thymine-tyrosine (DNA-histone protein) chromatin. ${ }^{50}$ Free Fe ions can cause $\mathrm{OH}$-mediated purine and pyrimidine modifications. ${ }^{105}$ As a result, Fe-containing NPs are a concern as a surplus source of Fe within the cells and fuelling the generation of highly reactive hydroxyl radicals via the Fenton reaction.

In addition to the elemental and ionic composition of NPs, the inherent high surface area can enhance the production of ROS. The smaller the NP, the higher the oxidative stress produced. ${ }^{106-110}$ Researchers have reported that silica

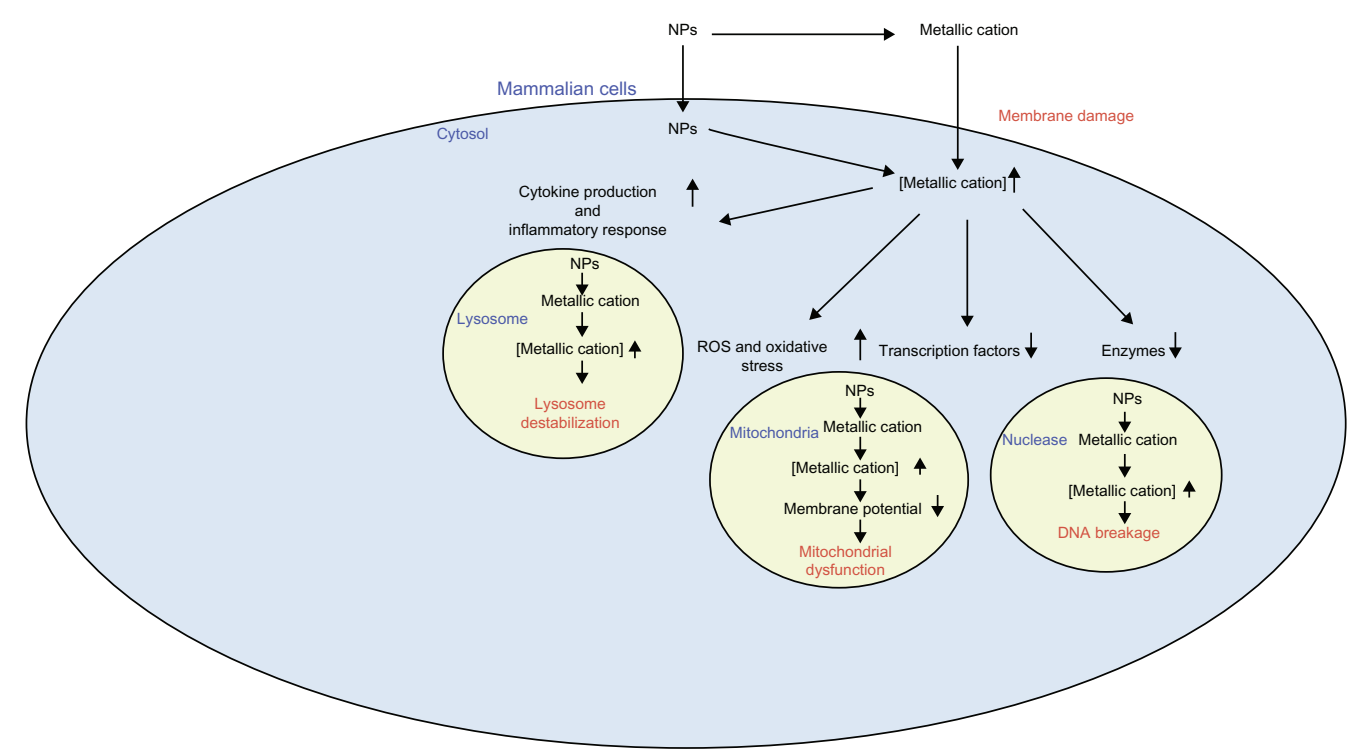

Figure 3 Key indirect mechanisms underlying nanogenotoxicity. Nanoparticles (NPs) may cause oxidative stress induction, inflammatory responses, or aberrant cellular signaling. These responses may be implicated in cancer risk.

Abbreviations: NPs, nanoparticles; ROS, reactive oxygen species. 


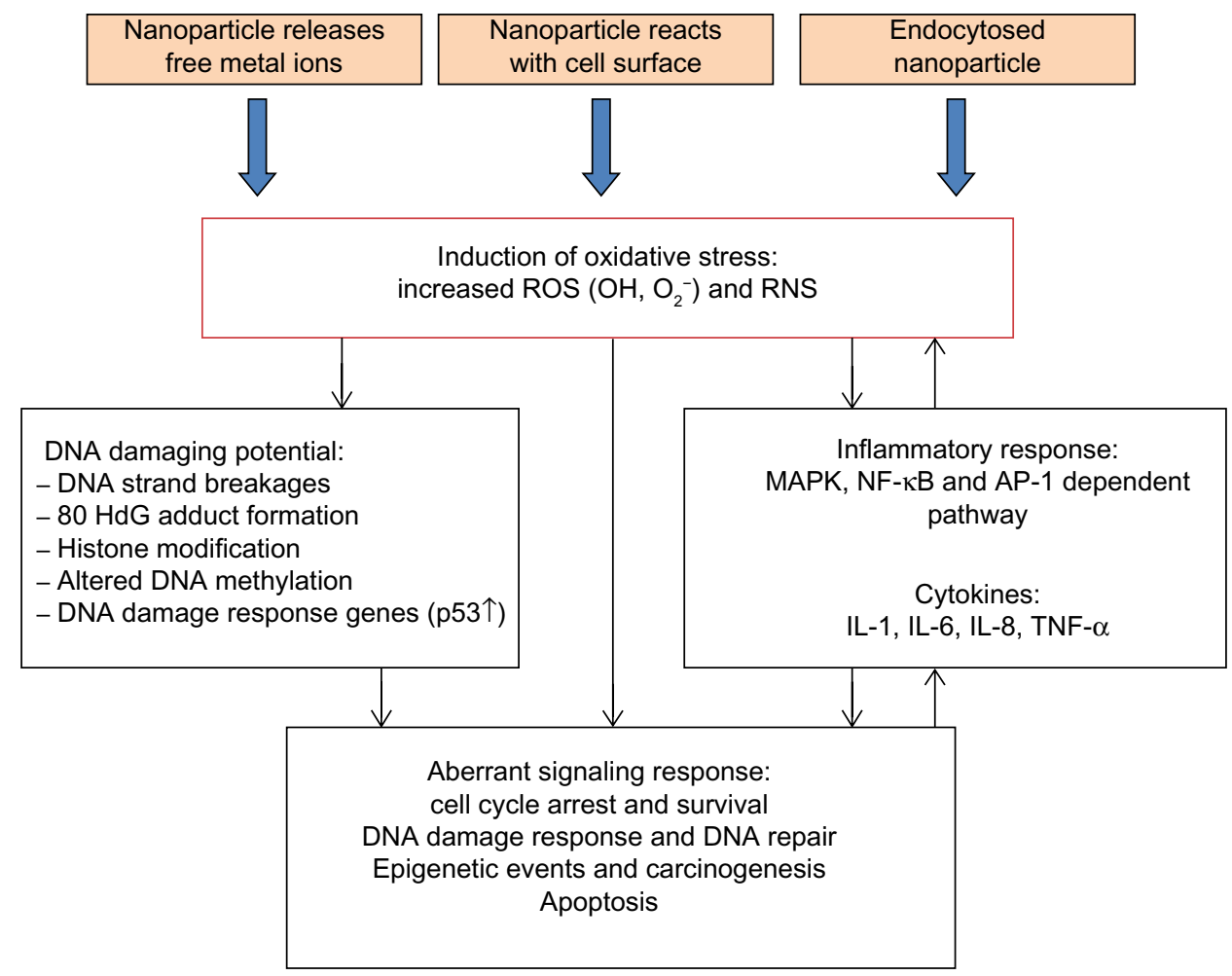

Figure 4 Putative mechanisms underlying the detrimental effects of zinc oxide and silica nanoparticles. These nanoparticles dissolve in the extracellular milieu, giving rise to increased extracellular metallic cations. This leads to increased intracellular respective metallic cations, resulting in decreased activity of particular enzymes and transcription factors. Moreover, this event can induce ROS generation and resulting oxidative stress, as well as stimulate various cytokine production and inflammatory responses. These phenomena, in turn, render membrane damage, DNA breakage, mitochondrial dysfunction, and lysosome destabilization.

Abbreviations: ROS, reactive oxygen species; RNS, reactive nitrogen species; IL, interleukin; TNF, tumor necrosis factor; NF- $\kappa B$, nuclear factor kappa-light-chain-enhancer of activated B cells; MAPK, mitogen-activated protein kinases; AP-I, activator protein I.

NP toxicity is dependent on size and may be associated with ROS generation. ${ }^{54,61,111}$

Oxidative DNA damage, as determined by the comet assay and micronucleus assay, ${ }^{108,112,113}$ has been demonstrated by several studies of the genotoxic effects of NPs. Oxidative stress activates specific signaling pathways, including mitogen-activated protein kinase and nuclear factor kappa B, ${ }^{114}$ together with interference of antioxidant defenses, resulting in release of proinflammatory cytokines. ${ }^{115}$ This signaling cascade is a key trigger of inflammation, a defensive reaction that leads to further ROS release from inflammatory cells (eg, neutrophils). ${ }^{116,117}$

\section{Inflammation}

Inflammation is an important physiological process in response to tissue injury mediated by inflammatory cells secreting cytokines (eg, interleukins and tumor necrosis factor protein families), migration inhibition factors, RNS (reactive nitrogen species), and ROS. These factors are involved in protective defense against infection and/or tissue injury. They promote DNA damage in the form of point mutations, DNA adducts, and chromosomal fragmentation, as well as inhibit
DNA repair and induce aberrant methylation patterns. ${ }^{60,61}$ Expectedly, chronic inflammation has been associated with carcinogenesis. $^{118,119}$

At present, a number of studies have shown that NPs can exhibit inflammatory responses. Their small size and great surface area are involved in facilitating inflammation, as previous studies demonstrate that ultrafine NPs display higher inflammatory potency in the lungs of rats following intratracheal instillation. ${ }^{120,121}$ The composition of the particle may be a determinant factor affecting the extent of the inflammatory response induced. For instance, in vitro, induced inflammation seems to follow the trend of silica and ZnO NPs. ${ }^{111,122,123}$ Some NPs have oxidative DNA damaging potential via excessive formation of ROS and the release of metal ions, but also as a consequence of chronic inflammatory responses.

\section{DNA damage responsive signaling}

Exposure to NPs is associated with induction of oxidative stress, leading to damage to cellular components, most importantly DNA. Consequently, this damage can affect several cellular responses, including cell cycle arrest, apoptosis, 
and DNA repair. The DNA repair system is responsible for genetic stability and cell survival, and if repair fails to occur during or before replication of damaged DNA, mutagenic and possibly carcinogenic incidences may occur.

Once DNA is damaged, a key effector molecule, p53, is activated. Tumor suppressor gene $\mathrm{p} 53$ has been recognized as "the guardian of the genome" because of its essential role in arresting the cell cycle, activating transcription of genes that mediate DNA repair, and preventing the incidence of mutagenic conversion. ${ }^{124}$ If DNA damage is extensively accumulated, p53 triggers apoptosis to eliminate the individual cell for the benefit of the organism. When these protective factors are compromised, stable heritable changes may undertake cellular transformation and, ultimately, carcinogenesis.

The pro-oxidative and proinflammatory properties have been found after exposure to various metal oxide NPs. ROS generation by $\mathrm{ZnO}$ NPs stimulates cellular processes: specifically, oxidant injury, inflammatory response, and cell death in different cell types such as mouse macrophages and human bronchial epithelial cells. ${ }^{77}$ Moreover, ZnO NPs are thought to be linked to the incidence of metal fume fever. A previous study has indicated that pro-oxidant activity of $\mathrm{ZnO}$ NPs is attributable to particle dissolution. ${ }^{125}$ Prevention of $\mathrm{ZnO}$ NP dissolution via Fe doping could decrease the pro-oxidative and proinflammatory effects of these particles. ${ }^{125}$ Other NPs (silica, cationic polystyrene, and C60 fullerene) have been reported to exhibit pro-oxidative and proinflammatory properties in vitro and in vivo, including extensive accumulation of ROS, induction of oxidative stress, and stimulation of antioxidant and signaling pathways. ${ }^{126-128}$

Indeed, several reports have demonstrated that exposure to asbestos fibers in unregulated workplaces risks pleural and lung fibrosis (asbestosis), lung cancer, and pleural and peritoneal malignant mesothelioma. ${ }^{129-131}$ Asbestos may be regarded as a tumor promoter or cocarcinogen in the induction of lung cancers, particularly representing synergistic effects with chemical carcinogens in cigarette smoke. ${ }^{132}$ Asbestos fibers are naturally occurring in rocks and soils and comprise six different types: amphibole types (crocidolite, amosite, anthophyllite, tremolite, and actinolite), which are rod-shaped and have higher durability relative to the only serpentine type (chrysotile). ${ }^{133}$ Much evidence has been presented that exposure to asbestos gives rise to a spectrum of asbestos-related diseases, including malignant pleural mesothelioma. This suggests an obvious relationship between the specific NP and disease, probably due to ROS accumulation and resulting oxidative stress. ${ }^{134-137}$ However, there is no currently published report addressing a definite correlation between a disease outcome and exposure to a specific type of newly developed NP in humans. An active approach should be taken as a precaution. One effective strategy is to identify biomarkers associated with NP exposure. ${ }^{138}$ Development of a panel of biomarkers as indicators of exposure-specific disease outcomes will require further time but would be well worth the effort for the identification of early biological responses related to current knowledge-based injury pathways.

Previous reports of metal fume fever, a flu-like illness with characteristics of self-limiting inflammation and oxidative stress response in the lung, indicate that it is caused by inhalation of highly concentrated metal oxide particles, particularly $\mathrm{ZnO} .{ }^{139-143}$ Given the increase in application of NPs and the uncertainty of their potential health impacts, health surveillance of workers frequently exposed to NPs in the occupational setting is important.

Using liquid chromatography-tandem mass spectrometry analysis, more than 30 proteins were thought to be responsible for incidental NP-induced oxidative stress. Some of these proteins may serve as markers for exposure to pro-oxidative substances. ${ }^{144,145}$ Alterations of other particle-induced proteomes include modification of nitrotyrosine-based protein, activation of unfolding protein response, and incremental expression of ATF4, an endoplasmic reticulum stress-related transcription factor. ${ }^{144,146}$ In animal studies, oxidative stressaltered proteomic profiles were found in the bronchoalveolar lavage fluid and lung tissue in mouse asthma models. ${ }^{147,148}$ A more recent study demonstrates the expression of polymeric immunoglobulin receptor, complement $\mathrm{C} 3$, neutrophil gelatinase-associated lipocalin, chitinase 3-like protein 3, chitinase 3 -like protein 4 , and acidic mammalian chitinase in the lung to be associated with the adjuvant effect of ultrafine particles on the oxidant activity and the primary immune response (allergic sensitization). ${ }^{148,149}$ Increased chitinase 3-like protein 3 expression is associated with the boosting of ambient ultrafine particles on the secondary immune response of inhalation exposure. ${ }^{150}$ Furthermore, alteration of oxidative stress-associated proteome was observed in the bronchoalveolar lavage fluid from C57BL/6 mice exposed to $\mathrm{ZnO} \mathrm{NP}$ via pharyngeal aspiration, indicating that proteomics may be used to identify biomarkers related to the exposure of certain NPs. Because oxidative stress and inflammatory response are also responsible for the toxicity of various NPs, the technology of proteomics has the potential to identify the biomarkers associated with NP exposure and the resulting deleterious effects of injury pathways.

The ideal biomarkers for evaluating environmental and occupational exposures should provide a mechanistic, 
molecular, and biological basis for the diseases and be exposure specific to reflect early adverse health effects, have clinical relevance, and be easy to use. Although identification of biomarkers that meet all these criteria is a challenge, it is feasible to study NP exposure-associated early biological events such as oxidative stress and inflammation.

\section{Artifacts and limitations influencing nanogenotoxicity studies}

Although little is known about the toxicokinetics of NPs, key factors gaining attention are the physicochemical properties influencing cellular uptake and subsequent physiological consequences. Parameters involved in genotoxicological responses are uncertain, and the evidence points to different factors participating in modulating molecular interactions.

\section{Size, shape, and surface area}

The nanometer size $(<100 \mathrm{~nm})$ of particles is considered a primary feature representing unique properties over bulk counterparts. Decreased size increases the number of particles per unit mass, but small size can also demonstrate a health hazard due to their interference with biological components once internalized. As a consequence, the size influences absorption, distribution, metabolism, and excretion kinetics, the driving force behind the development of new nanomedicines and nanodevices for clinical health care. ${ }^{6,7}$ With regard to cellular uptake, size is a key factor in the different internalization mechanisms. Perhaps the most prominent mechanism is diffusion across the plasma membrane (either directly across the membrane or through membrane channels 10-30 nm wide), endocytosis, or energy-dependent mechanisms via a number of different routes (Figure 1).

In addition to cellular uptake, size does influence toxicological outcome, as reported by many studies focusing on $\mathrm{ZnO}$ and silica NPs versus microparticles. For instance, inhalation studies show that NPs penetrate deeper into the lungs and become localized within various cell types, indicating a greater inflammatory response that is markedly associated with potential toxicity in comparison with their fine-sized counterparts. ${ }^{98,151-154}$ Although genotoxic potential was not examined in these investigations, the established relationship between chronic inflammation, DNA damage, and carcinogenesis may provide insight into the adverse health effects of long-term NP inhalation.

Shape or morphology is another matter related to negative cellular effects of NPs. Fewer studies focusing on the toxicological relationship associated with this parameter have been established, though a previous publication has demonstrated that removal of structural defects from a particular NP was sufficient to substantially reduce inflammatory response and overall toxicity. ${ }^{155}$ Previous studies have revealed that shape of NPs strongly governs uptake rate. Spherical NPs exhibit higher uptake than nanorods, whereas internalization of cylindrical materials is strongly influenced by a high aspect ratio. ${ }^{156,157}$

When the number of particles per mass unit increase, the overall surface area will also increase. The shape of NPs contributes to the overall surface area, such that spherical NPs have slightly smaller surface areas than an octagonal structure of the same size. This greater surface area promotes catalytic activity of the material, allowing an increase in its reactivity due to unsatisfied high energy bonds of surface atoms. ${ }^{120}$ If NPs are able to gain access to the cellular milieu, the large surface area will give rise to more reactivity with biological components, resulting in unwanted cellular damage and oxidative stress.

\section{Purity}

Purity of NPs is a concern, as contamination of residual metal may cause stronger (geno) toxicological responses than the actual nanomaterial. Most metal catalysts are removed by postproduction processes. Purified NPs may contain up to $15 \%$ metal residual bymass. Efforts to purify NPs are under way to limit effects of impurities on toxicity.

Numerous studies undertake the synthesis of lead-rich carbon nanotubes for use as X-ray protection shields. However, Fe is one of the primary sources of damage via oxidative stress, resulting in Fenton or Haber-Weiss reactions. ${ }^{158-161}$ Indeed, Fe contaminants on carbon nanotubes have reportedly been shown to cause a substantial loss of glutathione and increased lipid peroxidation in alveolar macrophages, indicators of oxidative stress. ${ }^{162}$ Conversely, a previous study found that single-walled carbon nanotubes induced dose-dependent lung lesions (granulomas) in mice, irregardless of purity. ${ }^{163}$ Similarly, nickel and yttrium catalyst impurities entrapped within single-walled carbon nanotubes and multiwalled carbon nanotubes do not seem to be responsible for potential toxicity associated with these materials. ${ }^{164}$ In general, in vitro studies utilizing metal chelators could provide more insight into the role of such impurities. However, the conflicting information may be attributed to the other physicochemical characteristics of NP used in the toxicological studies, and thus emphasizes the importance of full characterization and standardization of NPs. 


\section{Agglomeration (size distribution)}

An inherent feature of several NPs is their hydrophobicity and tendency to agglomerate, especially under physiological conditions. Upon exposure to biological systems, most NPs will form aggregates rather than remain monodisperse. In genotoxicity testing, in vivo or in vitro dosing in an aqueous carrier or into an aqueous environment (with the exception of dust inhalation studies) is usually established, and exposure responses relate to the degree of agglomerated NP form. ${ }^{165}$

Although NPs have a tendency to form larger aggregates, fibrous NPs represent a more complex situation. In addition to aggregation, the fibers may form a tangled structure depending upon rigidity, leading to a change in the dimensions and surface area of the original structure. Although fiber rigidity is dependent on the synthesis method, rigid NPs are attracted to one another by van der Waals forces, with a tendency to curve and twist, forming bundles. ${ }^{16,167}$ Agglomerates are larger and often more rigid than individual NPs, leading to new causes of toxicity. ${ }^{168}$

Different approaches are being undertaken to improve the hydrophilicity of NPs. Concerning dissolution of NPs in suspension media, aggregation/agglomeration is still an obstacle due to van der Waals forces and resulting adhesion toward particles at nanoscale. Hence, efforts on dispersal methods are established to improve their solubilities by using various dispersing agents of both inorganic and organic stabilizers (eg, fetal serum, organosulfur compounds, polyethyleneglycol, dextran, liposomes, micelles) or chemically modified functionalization of particle surface (eg, polymeric macromolecules). ${ }^{100,169-171}$

Indeed, the aggregate states can be overcome by use of organic small molecules harboring multiple functional groups such as carboxyl $(\mathrm{COOH})$, amine $\left(\mathrm{NH}_{2}\right)$, thiol $(\mathrm{SH})$, phosphate, and sulfates. These stabilizers can be tailored for dispersibility into aqueous media or other biocompatible fluids. ${ }^{172,173}$ The organosulfur compound 2,3-meso dimercaptosuccinic acid (DMSA) containing two carboxylic and two thiol groups has been widely applied as a dispersing stabilizer. Magnetic NPs have been stabilized with DMSA for tissue- and cell-targeted delivery of therapeutic drugs in the lung. ${ }^{174}$ In particular, the mechanism of proinflammatory effects of magnetic NPs and DMSA has been examined. Also, the postfunctionalization of NPs using methoxy polyethyleneglycol (PEG) 2000 silane has been successfully developed for stabilizing free thiols onto the surface of metal oxide NPs under physiological $\mathrm{pH} .{ }^{175}$

Moreover, various polymer molecules have been employed for steric stabilization of oxide NPs in aqueous and high ionic strength media. ${ }^{176-178}$ These polymeric stabilizers can affect the performance of nanomaterials, depending on the chemical nature of the polymer (ie, hydrophilicity/hydrophobicity, biocompatibility, and biodegradation), the molecular weight of the polymer, the conformation of the polymer, and the degree of particle surface. Other stabilizers, such as the amphiphilic molecules (eg, liposomes and micelles), have been successfully utilized to improve hydrophilicity of oxide NPs in biological or physiological media. ${ }^{179,180}$

The features of solubility or dispersity usually influence cytotoxic and genotoxic impact; however, these issues should be treated with caution. Previous reports have demonstrated that surface modification-solubilized NPs can alleviate toxicity as a result of the functionalization. ${ }^{181,182}$ Conversely, several studies have shown the surfactant-stabilized NPs to be more cytotoxic, and coating NPs with gold and silver apparently augments cytotoxicity in comparison with nondispersed or noncoated counterparts. ${ }^{183}$

Extensive effort is necessary to refine the interplay between agglomeration, dispersal methods, and negative cellular effects. The degree of agglomeration under experimental conditions when conducting risk assessment may provide clearer interpretation of results. ${ }^{184,185}$ Given that agglomerated structure may not be in the nanoscale, risks regarding exposure may be substantially decreased due to reduced cellular uptake or an inability to cross biological barriers. However, overlooking the agglomeration-related issues in many studies may be a primary cause for the lack of consistency and often conflicting reports.

\section{Surface charge and chemistry}

An understanding of surface properties of NPs is essential for providing insight into their behavior under different experimental conditions. Surface charge and chemistry will influence the production of agglomerates and resulting toxicities according to factors such as the $\mathrm{pH}$ or ionic strength in the aqueous environment. ${ }^{186}$ Thus, aggregation/disaggregation kinetics may be useful to decipher toxicities that may occur during the course of an in vitro experiment or according to the specific biological compartment where the NPs may become concentrated.

Surface charge has an important role in regulating cellular uptake of NPs. The plasma membrane is negatively charged (due to the phospholipids on the outer surface), as well as the intracellular environment. Thus, anionic NPs may be endocytosed at a lower rate compared with cationic NPs. Although this has been observed in practice using PEGylated polylactide and hydrogel NPs of similar sizes but varying charges, ${ }^{157,187}$ this effect does not preclude the uptake of negatively charged NPs. ${ }^{188}$ However, cationic surface charges show greater cytotoxic responses as compared with those with 
anionic charges, although it is uncertain whether cell death is a direct consequence of surface charge or a result of increased uptake often associated with cationic NPs. ${ }^{189}$ Furthermore, DNA is negatively charged. Thus, cationic NPs appear to interact more significantly with genetic material.

In addition to functionalizing the surface to promote their solubility, surface chemistry may be modified to attach biological components such as peptides for cell targeting or pharmaceuticals for drug delivery. These modifications will have toxicological impact toward the resultant NPs because cytotoxicity is strongly associated with coating the functional group. ${ }^{190}$ Information on surface charge and chemistries is significant in elucidating uptake mechanisms and predicting biological interactions for the evaluation of toxicity.

\section{Concluding remarks for nano(geno) toxicological studies}

Currently, inadequate information on the genotoxic potential of NPs and the impact on persistent exposure to human health is a concern. Numerous literature reports focus on the cytotoxicity of NPs, specific aspects of physicochemical characteristics, association with other potential toxic effects, as well as consideration of DNA damage and cellular uptake, bioaccumulation, distribution, and retention. A growing body of studies point to particular NPs eliciting DNA damage potential, but inconclusive reports necessitate a discussion within the scientific community for clearer and more informative reports. Previous reviews have addressed potential considerations, including material characterization, use of standardized experimental methods, and association between in vitro and in vivo results, ${ }^{191,192}$ but should account for the following.

1. In toxicological studies of any NPs, detailed physicochemical characterization under real experimental conditions is preferential. Measurements should include size distribution, morphology, surface area, charge, surface modifications, chemical composition, crystallinity, and agglomeration. Moreover, information on the fabrication process should be provided.

2. Appropriate controls (positives and negatives) and standards need to be established. Sources of metal ions or the use of metal chelators should be addressed in experimental design to elucidate whether biological effects are the consequence of NP interactions, impurities, or degradation products released during exposure.

3. If the functionalized form of NPs is being assessed, the unfunctionalized form should also be included to directly investigate the effect of the surface modification.
4. NP dynamics during the period of genotoxicity assay need to be a concern: eg, what about the degree of agglomeration and size distribution? In vitro, do NPs sediment or remain in suspension? Metrological techniques required to provide clearer information are currently not available and need to be developed.

5. Once internalized, the long-term fate of NPs needs to be considered. Physicochemical properties before and after experimentation should be detailed but may require the development of novel methodologies to form answers.

6. A battery of genotoxicity tests with varying end points should be utilized to provide insight into the mechanism of action and to ensure a comprehensive view of the reactivity of NPs.

7. In addition to somatic cells, the genotoxic potential of NPs on germ cells should be conducted.

8. Extension of in vitro experiments over 24 hours might be necessary if longer treatment times are more informative on the genotoxic potential of NPs.

Well-designed experiments are needed to enable a concerted effort to better exploit NP-mediated hazards and to define similarities enabling further extrapolations. The underlying mechanisms responsible for the exposure effect observed is also important in effectively informing the safer design of future NP systems, ensuring biocompatibility with minimum deleterious health risks. Biomarker studies provide valuable information identifying early biological events associated with adverse health effects of engineered nanomaterials before the manifestation of clinical outcomes, potentially helping health surveillance of workers at higher risk due to their occupational settings.

\section{Acknowledgments}

This research was supported by a grant (10182MFDS991) from the Ministry of Food and Drug Safety in 2010-13 and 'The Ecoinnovation Project' (412-112-110) by the Korean Ministry of Environment. This research project is also supported by a grant from Mahidol University, Thailand, and a grant from the Faculty of Environment and Resource Studies, Mahidol University, Thailand.

\section{Disclosure}

The authors report no conflicts of interest in this work.

\section{References}

1. Singh N, Manshian B, Jenkins GJ, et al. NanoGenotoxicology: the DNA damaging potential of engineered nanomaterials. Biomaterials. 2009;30(23-24):3891-3914. 
2. Lux report. Nanomaterials state of the market: stealth success, broad impact. Available from: http://portal.luxresearchinc.com/research/ document/3735. Accessed January 17, 2008.

3. Brown C, Fisher J, Ingham E. Biological effects of clinically relevant wear particles from metal-on-metal hip prostheses. Proc Inst Mech Eng H. 2006;220(2):355-369.

4. Ballestri M, Baraldi A, Gatti AM, et al. Liver and kidney foreign bodies granulomatosis in a patient with malocclusion, bruxism, and worn dental prostheses. Gastroenterology. 2001;121(5):1234-1238.

5. Hart AJ, Hester T, Sinclair K, et al. The association between metal ions from hip resurfacing and reduced T-cell counts. J Bone Joint Surg Br. 2006;88(4):449-454.

6. Ferrari M. Cancer nanotechnology: opportunities and challenges. Nat Rev Cancer. 2005;5(3):161-171.

7. Sahoo SK, Parveen S, Panda JJ. The present and future of nanotechnology in human health care. Nanomedicine. 2007;3(1):20-31.

8. Du X, He J. Elaborate control over the morphology and structure of mercapto-functionalized mesoporous silicas as multipurpose carriers. Dalton Trans. 2010;39(38):9063-9072.

9. Ma S WY, Zhu Y. A simple room temperature synthesis of mesoporous silica nanoparticles for drug storage and pressure pulsed delivery. Journal of Porous Material. 2011;18(2):233-239.

10. Barick KC, Nigam S, Bahadur D. Nanoscale assembly of mesoporous ZnO: a potential drug carrier. J Mater Chem. 2010;20:6446-6452.

11. Borm PJA, Berube D. A tale of opportunities, uncertainties and risks. Nano Today. 2008;3:56-59.

12. Dusinska M, Fjellsbo L, Magdolenova Z, et al. Testing strategies for the safety of nanoparticles used in medical applications. Nanomedicine (Lond). 2009;4(6):605-607.

13. Kumar A, Pandey A, Shanker R, Dhawan A. Microorganism: a versatile model for toxicity assessment of engineered nanomaterials. In: Cioffi N, Rai M, editors. Nano-Antimicrobials: Progress and Prospects. Berlin, Germany: Springer Verlag GmbH, 2012.

14. Maynard AD. Nanotechnology: the next big thing, or much ado about nothing? Ann Occup Hyg. 2007;51:1-12.

15. Elsaesser A, Howard CV. Toxicology of nanoparticles. Adv Drug Deliv Rev. 2012;64(2):129-137.

16. Navarro E, Baun A, Behra R, et al. Environmental behavior and ecotoxicity of engineered nanoparticles to algae, plants, and fungi. Ecotoxicology. 2008;17(5):372-386.

17. Kumar A, Pandey AK, Singh SS, Shanker R, Dhawan A. A flow cytometric method to assess nanoparticle uptake in bacteria. Cytometry A. 2011;79(9):707-712.

18. Aitken RJ, Koopman P, Lewis SE. Seeds of concern. Nature. 2004; 432(7013):48-52.

19. Aitken RJ HS, Tran CL, Donaldson K, et al. Multidisciplinary approach to the identification of reference materials for engineered nanoparticle toxicology. Nanotoxicology. 2008;2:71-78.

20. Feliu N, Fadeel B. Nanotoxicology: no small matter. Nanoscale. 2010;2(12):2514-2520.

21. Pan H, House MG, Hao X, Jiang HW. Fabrication and characterization of a silicon metal-oxide-semiconductor based triple quantum dot. Appl Phys Lett. 2012;100(263109):1-5.

22. Shpaisman N, Givan U, Kwiat M, Pevzner A, Elnathan R, Patolsky F. Controlled synthesis of ferromagnetic semiconducting silicon nanotubes. J Phys Chem C. 2012;116(14):8000-8007.

23. Sachet E, Losego MD, Guske J, Franzen S, Maria JP. Mid-infrared surface plasmon resonance in zinc oxide semiconductor thin films. Appl Phys Lett. 2013;102(5):051111-051114.

24. Rowe DJ, Jeong JS, Mkhoyan KA, Kortshagen UR. Phosphorus-doped silicon nanocrystals exhibiting mid-infrared localized surface plasmon resonance. Nano Lett. 2013;13(3):1317-1322.

25. Zhou WJ, Halpern AR, Seefeld TH, Corn RM. Near infrared surface plasmon resonance phase imaging and nanoparticle-enhanced surface plasmon resonance phase imaging for ultrasensitive protein and DNA biosensing with oligonucleotide and aptamer microarrays. Anal Chem. 2012;84(1):440-445.
26. Joshi R, Feldmann V, Koestner W, et al. Multifunctional silica nanoparticles for optical and magnetic resonance imaging. Biological Chemistry. 2013;394(1):125-135.

27. Orlov AF, Agagonov Y, Balagurov LA, Bublik VT, et al. Study of structural characteristics of ferromagnetic silicon implanted with manganese. Crystallography Reports. 2008;53(5):796-799.

28. Science Daily. Nanoparticle. Available from: http://www.sciencedaily. com/articles/n/nanoparticle.htm. Accessed February 17, 2013.

29. Dufour EK, Kumaravel T, Nohynek GJ, Kirkland D, Toutain H. Clastogenicity, photo-clastogenicity or pseudo-photo-clastogenicity: genotoxic effects of zinc oxide in the dark, in pre-irradiated or simultaneously irradiated Chinese hamster ovary cells. Mutat Res. 2006; 607(2):215-224.

30. Yuan Fangli HP, Yin Chunlei, Huang Shulan, Li Jinlin. Preparation and properties of zinc oxide nanoparticles coated with zinc aluminate. J Mater Chem. 2003;13:634-637.

31. Qi Qi TZ, Qingjiang Yu, Rui Wang, Yi Zeng, Li Liu, Haibin Yang. Properties of humidity sensing $\mathrm{ZnO}$ nanorods-base sensor fabricated by screen-printing. Sens Actuators B Chem. 2008;133:638-643.

32. Sayes CM, Reed KL, Warheit DB. Assessing toxicity of fine and nanoparticles: comparing in vitro measurements to in vivo pulmonary toxicity profiles. Toxicol Sci. 2007;97(1):163-180.

33. Jeng HA, Swanson J. Toxicity of metal oxide nanoparticles in mammalian cells. J Environ Sci Health A Tox Hazard Subst Environ Eng. 2006;41(12):2699-2711.

34. Kumar A, Dhawan A. Genotoxic and carcinogenic potential of engineered nanoparticles: an update. Arch Toxicol. 2013;87(11):1883-1900.

35. Manke A, Wang L, Rojanasakul Y. Mechanisms of nanoparticle-induced oxidative stress and toxicity. Biomed Res Int. 2013;2013:942916.

36. Sharma V, Singh P, Pandey AK, Dhawan A. Induction of oxidative stress, DNA damage and apoptosis in mouse liver after sub-acute oral exposure to zinc oxide nanoparticles. Mutat Res. 2012;745(1-2):84-91.

37. Surekha P, Kishore AS, Srinivas A, et al. Repeated dose dermal toxicity study of nano zinc oxide with Sprague-Dawley rats. Cutan Ocul Toxicol. 2012;31(1):26-32.

38. Rob J Vandebriel, Wim H De Jong. A review of mammalian toxicity of ZnO nanoparticles. Nanotechnol Sci Appl. 2012;5:61-71.

39. Sharma V, Shukla RK, Saxena N, Parmar D, Das M, Dhawan A. DNA damaging potential of zinc oxide nanoparticles in human epidermal cells. Toxicol Lett. 2009;185(3):211-218.

40. Yeon Sue Jang, Eun Young Lee, Yoon-Hee Park. The potential for skin irritation, phototoxicity, and sensitization of $\mathrm{ZnO}$ nanoparticles. $\mathrm{Mol}$ Cell Toxicol. 2012;8(2):171-177.

41. Seung Ho Lee, Jae Eun Pie, Yu Ri Kim, Hee Ra Lee, Sang Wook Son, Meyoung-Kon Kim. Effects of zinc oxide nanoparticles on gene expression profile in human keratinocytes. Mol Cell Toxicol. 2012; $8(2): 113-118$

42. SCCNFP. The scientific committee on cosmetic products and non-food products intended for consumers concerning zinc oxide. 2003. Available from: http://ec.europa.eu/health/ph_risk/committees/sccp/documents/ out222_en.pdf. Accessed April 15, 2014.

43. Wang SQ, Balagula Y, Osterwalder U. Photoprotection: a review of the current and future technologies. Dermatol Ther. 2010;23(1):31-47.

44. Tran DT, Salmon R. Potential photocarcinogenic effects of nanoparticle sunscreens. Australas J Dermatol. 2011;52(1):1-6.

45. Kaewamatawong T, Shimada A, Okajima M, et al. Acute and subacute pulmonary toxicity of low dose of ultrafine colloidal silica particles in mice after intratracheal instillation. Toxicol Pathol. 2006;34(7):958-965.

46. Lin W, Huang YW, Zhou XD, Ma Y. In vitro toxicity of silica nanoparticles in human lung cancer cells. Toxicol Appl Pharmacol. 2006; 217(3):252-259.

47. Chang JS, Chang KL, Hwang DF, Kong ZL. In vitro cytotoxicitiy of silica nanoparticles at high concentrations strongly depends on the metabolic activity type of the cell line. Environ Sci Technol. 2007; 41(6):2064-2068.

48. Jin Y, Kannan S, Wu M, Zhao JX. Toxicity of luminescent silica nanoparticles to living cells. Chem Res Toxicol. 2007;20(8):1126-1133. 
49. Chen M, von Mikecz A. Formation of nucleoplasmic protein aggregates impairs nuclear function in response to $\mathrm{SiO} 2$ nanoparticles. Exp Cell Res. 2005;305(1):51-62.

50. Valko M, Rhodes CJ, Moncol J, Izakovic M, Mazur M. Free radicals, metals and antioxidants in oxidative stress-induced cancer. Chem Biol Interact. 2006;160(1):1-40.

51. Barnes CA, Elsaesser A, Arkusz J, et al. Reproducible comet assay of amorphous silica nanoparticles detects no genotoxicity. Nano Lett. 2008;8(9):3069-3074.

52. Wang JJ, Sanderson BJ, Wang H. Cytotoxicity and genotoxicity of ultrafine crystalline $\mathrm{SiO} 2$ particulate in cultured human lymphoblastoid cells. Environ Mol Mutagen. 2007;48(2):151-157.

53. Fruijtier-Polloth $\mathrm{C}$. The toxicological mode of action and the safety of synthetic amorphous silica-a nanostructured material. Toxicology 2012;294(2-3):61-79.

54. Park YH, Bae CH, Jang Y. Effect of the size and surface charge of silica nanoparticles on cutaneous toxicity. Mol Cell Toxicol. 2013;9(1): 67-74.

55. Musa M, Kannan TP, Masudi SM, Ab Rahman I. Assessment of DNA damage caused by locally produced hydroxyapatite-silica nanocomposite using comet assay on human lung fibroblast cell line. Mol Cell Toxicol. 2012;8(1):53-60.

56. Choi JE, Park Y-H, Young Lee E. A safety assessment of phototoxicity and sensitization of $\mathrm{SiO} 2$ nanoparticles. Mol Cell Toxicol. 2011;7(2):171-176.

57. Kim Y-J, Ik Yang S. Neurotoxic effects by silica TM nanoparticle is independent of differentiation of SH-SY5Y cells. Mol Cell Toxicol. 2011;7(4):381-388.

58. Yoshida T, Yoshioka Y, Matsuyama K, et al. Surface modification of amorphous nanosilica particles suppresses nanosilica-induced cytotoxicity, ROS generation, and DNA damage in various mammalian cells. Biochem Biophys Res Commun. 2012;427(4):748-752.

59. Wang F, Jiao C, Liu J, Yuan H, Lan M, Gao F. Oxidative mechanisms contribute to nanosize silican dioxide-induced developmental neurotoxicity in PC12 cells. Toxicol In Vitro. 2011;25(8):1548-1556.

60. Sergent JA, Paget V, Chevillard S. Toxicity and genotoxicity of nano$\mathrm{SiO} 2$ on human epithelial intestinal HT-29 cell line. Ann Occup Hyg. 2012;56(5):622-630

61. Passagne I, Morille M, Rousset M, Pujalte I, L’Azou B. Implication of oxidative stress in size-dependent toxicity of silica nanoparticles in kidney cells. Toxicology. 2012;299(2-3):112-124.

62. Nabeshi H, Yoshikawa T, Matsuyama K, et al. Amorphous nanosilica induce endocytosis-dependent ROS generation and DNA damage in human keratinocytes. Part Fibre Toxicol. 2011;8:1.

63. Landsiedel R, Ma-Hock L, Van Ravenzwaay B, et al. Gene toxicity studies on titanium dioxide and zinc oxide nanomaterials used for UV-protection in cosmetic formulations. Nanotoxicology. 2010;4:364-381.

64. Li CH, Shen CC, Cheng YW, et al. Organ biodistribution, clearance, and genotoxicity of orally administered zinc oxide nanoparticles in mice. Nanotoxicology. 2012;6(7):746-756.

65. Monteiro-Riviere NA, Wiench K, Landsiedel R, Schulte S, Inman AO, Riviere JE. Safety evaluation of sunscreen formulations containing titanium dioxide and zinc oxide nanoparticles in UVB sunburned skin: an in vitro and in vivo study. Toxicol Sci. 2011;123(1):264-280

66. Gopalan R, Osman I, Amani A, Matas M, Anderson D. The effect of zinc oxide and titanium dioxide nanoparticles in the comet assay with UVA photoactivation of human sperm and lymphocytes. Nanotoxicology. 2009;3(1):33-39.

67. Gerloff K, Albrecht C, Boots AW, Förster I, Schins RPF. Cytotoxicity and oxidative DNA damage by nanoparticles in human intestinal Caco-2 cells. Nanotoxicology. 2009;3(4):355-364.

68. Yang H, Liu C, Yang D, Zhang H, Xi Z. Comparative study of cytotoxicity, oxidative stress and genotoxicity induced by four typical nanomaterials: the role of particle size, shape and composition. $J \mathrm{Appl}$ Toxicol. 2009;29(1):69-78.

69. Yoshida R, Kitamura D, Maenosono S. Mutagenicity of water-soluble ZnO nanoparticles in Ames test. J Toxicol Sci. 2009;34(1):119-122.
70. Osman IF, Baumgartner A, Cemeli E, Fletcher JN, Anderson D. Genotoxicity and cytotoxicity of zinc oxide and titanium dioxide in HEp-2 cells. Nanomedicine (Lond). 2010;5(8):1193-1203.

71. Yin H, Casey PS, McCall MJ, Fenech M. Effects of surface chemistry on cytotoxicity, genotoxicity, and the generation of reactive oxygen species induced by ZnO nanoparticles. Langmuir. 2010;26(19): 15399-15408.

72. Sharma V, Anderson D, Dhawan A. Zinc oxide nanoparticles induce oxidative stress and genotoxicity in human liver cells (HepG2). J Biomed Nanotechnol. 2011;7(1):98-99.

73. Sharma V, Singh SK, Anderson D, Tobin DJ, Dhawan A. Zinc oxide nanoparticle induced genotoxicity in primary human epidermal keratinocytes. J Nanosci Nanotechnol. 2011;11(5):3782-3788.

74. Hackenberg S, Zimmermann FZ, Scherzed A, et al. Repetitive exposure to zinc oxide nanoparticles induces dna damage in human nasal mucosa mini organ cultures. Environ Mol Mutagen. 2011;52(7):582-589.

75. Yin H, Casey PS, McCall MJ. Surface modifications of $\mathrm{ZnO}$ nanoparticles and their cytotoxicity. J Nanosci Nanotechnol. 2010;10(11): 7565-7570.

76. Zhang XQ, Yin LH, Tang M, Pu YP. ZnO, TiO(2), $\mathrm{SiO}(2$, ) and $\mathrm{Al}(2)$ $\mathrm{O}(3)$ nanoparticles-induced toxic effects on human fetal lung fibroblasts. Biomed Environ Sci. 2011;24(6):661-669.

77. Xia T, Kovochich M, Liong M, et al. Comparison of the mechanism of toxicity of zinc oxide and cerium oxide nanoparticles based on dissolution and oxidative stress properties. ACS Nano. 2008;2(10) 2121-2134

78. De Berardis B, Civitelli G, Condello M, et al. Exposure to ZnO nanoparticles induces oxidative stress and cytotoxicity in human colon carcinoma cells. Toxicol Appl Pharmacol. Epub April 29, 2010.

79. Sharma V, Anderson D, Dhawan A. Zinc oxide nanoparticles induce oxidative DNA damage and ROS-triggered mitochondria mediated apoptosis in human liver cells (HepG2). Apoptosis. 2012;17(8): $852-870$.

80. Alarifi S, Ali D, Alkahtani S, et al. Induction of oxidative stress, DNA damage, and apoptosis in a malignant human skin melanoma cell line after exposure to zinc oxide nanoparticles. Int J Nanomedicine. 2013;8:983-993.

81. Guo D, Bi H, Liu B, Wu Q, Wang D, Cui Y. Reactive oxygen speciesinduced cytotoxic effects of zinc oxide nanoparticles in rat retinal ganglion cells. Toxicol In Vitro. 2013;27(2):731-738.

82. Johnston CJ, Driscoll KE, Finkelstein JN, et al. Pulmonary chemokine and mutagenic responses in rats after subchronic inhalation of amorphous and crystalline silica. Toxicol Sci. 2000;56(2):405-413.

83. Sayes CM, Reed KL, Glover KP, et al. Changing the dose metric for inhalation toxicity studies: short-term study in rats with engineered aerosolized amorphous silica nanoparticles. Inhal Toxicol. 2010;22(4): $348-354$.

84. Liu X, Keane MJ, Zhong BZ, Ong TM, Wallace WE. Micronucleus formation in V79 cells treated with respirable silica dispersed in medium and in simulated pulmonary surfactant. Mutat Res. 1996; 361(2-3):89-94.

85. ECETOC. European Centre for Ecotoxicology and Toxicology of Chemicals. Synthetic amorphous silica (CAS No 7631-86-9). Brussels, Belgium: JACC Report; 2006:237.

86. EPA. US Environmental Protection Agency. Screening-level hazard characterization of silane, dichlorodimethyl-, reaction product with silica (CASRN 68611-44-9); 2011.

87. OECD. Organisation for Economic Co-operation and Development SIDS dossier on synthetic amorphous silica and silicates; 2004.

88. Yang K, Lin D, Xing B. Interactions of humic acid with nanosized inorganic oxides. Langmuir. 2009;25(6):3571-3576.

89. Gonzalez L, Thomassen LC, Plas G, et al. Exploring the aneugenic and clastogenic potential in the nanosize range: A549 human lung carcinoma cells and amorphous monodisperse silica nanoparticles as models. Nanotoxicology. 2010;4:382-395.

90. Park MV, Verharen HW, Zwart E, et al. Genotoxicity evaluation of amorphous silica nanoparticles of different sizes using the micronucleus and the plasmid lacZ gene mutation assay. Nanotoxicology. 2011;5(2):168-181. 
91. Park YH, Kim JN, Jeong SH, et al. Assessment of dermal toxicity of nanosilica using cultured keratinocytes, a human skin equivalent model and an in vivo model. Toxicology. 2010;267(1-3):178-181.

92. Wang F, Gao F, Lan M, Yuan H, Huang Y, Liu J. Oxidative stress contributes to silica nanoparticle-induced cytotoxicity in human embryonic kidney cells. Toxicol In Vitro. 2009;23(5):808-815.

93. Ye Y, Liu J, Xu J, Sun L, Chen M, Lan M. Nano-SiO2 induces apoptosis via activation of p53 and Bax mediated by oxidative stress in human hepatic cell line. Toxicol In Vitro. 2010;24(3):751-758.

94. Ye Y, Liu J, Chen M, Sun L, Lan M. In vitro toxicity of silica nanoparticles in myocardial cells. Environ Toxicol Pharmacol. 2010;29(2): 131-137.

95. Chen Q, Xue Y, Sun J. Kupffer cell-mediated hepatic injury induced by silica nanoparticles in vitro and in vivo. Int J Nanomedicine. 2013;8: 1129-1140.

96. Park Y-H, Bae HC, Jang Y, et al. Effect of the size and surface charge of silica nanoparticles on cutaneous toxicity. Mol Cell Toxicol. 2013;9(1):67-74.

97. Magdolenova Z, Collins A, Kumar A, Dhawan A, Stone V, Dusinska M. Mechanisms of genotoxicity. A review of in vitro and in vivo studies with engineered nanoparticles. Nanotoxicology. 2014;8:233-278.

98. Geiser M, Rothen-Rutishauser B, Kapp N, et al. Ultrafine particles cross cellular membranes by nonphagocytic mechanisms in lungs and in cultured cells. Environ Health Perspect. 2005;113(11): 1555-1560.

99. Liu L, Takenaka T, Zinchenlco AA, et al. Cationic silica nanoparticles are efficiently transferred into mammalian cells. Micro-NanoMechatronics and Human Science. International Symposium on MHS '07. 2007: 281-285.

100. Yeo MK, HG Park. Gene expression in zebrafish embryos following exposure to $\mathrm{Cu}$-doped $\mathrm{TiO} 2$ and pure $\mathrm{TiO} 2$ nanometer-sized photocatalysts. Mol Cell Toxicol. 2012;8(2):127-137.

101. Yeo MK, Kang M. The biological toxicities of two crystalline phases and differential sizes of TiO2 nanoparticles during zebrafish embryogenesis development. Mol Cell Toxicol. 2012;8(4):317-326.

102. Nabiev I, Mitchell S, Davies A, et al. Nonfunctionalized nanocrystals can exploit a cell's active transport machinery delivering them to specific nuclear and cytoplasmic compartments. Nano Lett. 2007;7(11): 3452-3461.

103. Toyokuni S. Oxidative stress and cancer: the role of redox regulation. Biotherapy. 1998;11(2-3):147-154.

104. Rim KT, Kim SJ, Song SW, Park JS. Effect of cerium oxide nanoparticles to inflammation and oxidative DNA damages in $\mathrm{H} 9 \mathrm{c} 2$ cells. Mol Cell Toxicol. 2012;8(3):271-280.

105. Zastawny TH, Altman SA, Randers-Eichhorn L, et al. DNA base modifications and membrane damage in cultured mammalian cells treated with iron ions. Free Radic Biol Med. 1995;18(6):1013-1022.

106. Brown DM, Wilson MR, MacNee W, Stone V, Donaldson K. Sizedependent proinflammatory effects of ultrafine polystyrene particles: a role for surface area and oxidative stress in the enhanced activity of ultrafines. Toxicol Appl Pharmacol. 2001;175(3):191-199.

107. Knaapen AM, Borm PJ, Albrecht C, Schins RP. Inhaled particles and lung cancer. Part A: mechanisms. Int J Cancer. 2004;109(6): 799-809.

108. Karlsson HL, Cronholm P, Gustafsson J, Moller L. Copper oxide nanoparticles are highly toxic: a comparison between metal oxide nanoparticles and carbon nanotubes. Chem Res Toxicol. 2008;21(9): $1726-1732$.

109. Lee BC, Kim KT, Cho JG, et al. Oxidative stress in juvenile common carp (Cyprinus carpio) exposed to $\mathrm{TiO} 2$ nanoparticles. Mol Cell Toxicol. 2012;8(4):357-366.

110. Park H-G, Yeo M-K. Comparison of gene expression changes induced by exposure to $\mathrm{Ag}, \mathrm{Cu}-\mathrm{TiO} 2$, and $\mathrm{TiO} 2$ nanoparticles in zebrafish embryos. Mol Cell Toxicol. 2013;9(2):129-139.

111. Park EJ, Yi J, Chung KH, Ryu DY, Choi J, Park K. Oxidative stress and apoptosis induced by titanium dioxide nanoparticles in cultured BEAS-2B cells. Toxicol Lett. 2008;180(3):222-229.
112. Papageorgiou I, Brown C, Schins R, et al. The effect of nano- and micron-sized particles of cobalt-chromium alloy on human fibroblasts in vitro. Biomaterials. 2007;28(19):2946-2958.

113. Gurr JR, Wang AS, Chen CH, Jan KY. Ultrafine titanium dioxide particles in the absence of photoactivation can induce oxidative damage to human bronchial epithelial cells. Toxicology. 2005;213(1-2):66-73.

114. Bonvallot V, Baeza-Squiban A, Baulig A, et al. Organic compounds from diesel exhaust particles elicit a proinflammatory response in human airway epithelial cells and induce cytochrome p450 1A1 expression. Am J Respir Cell Mol Biol. 2001;25(4):515-521.

115. Abe S, Takizawa H, Sugawara I, Kudoh S. Diesel exhaust (DE)induced cytokine expression in human bronchial epithelial cells: a study with a new cell exposure system to freshly generated DE in vitro. Am J Respir Cell Mol Biol. 2000;22(3):296-303.

116. Donaldson K, Tran CL. An introduction to the short-term toxicology of respirable industrial fibres. Mutat Res. 2004;553(1-2):5-9.

117. Waldman WJ, Kristovich R, Knight DA, Dutta PK. Inflammatory properties of iron-containing carbon nanoparticles. Chem Res Toxicol. 2007;20(8):1149-1154.

118. Blanco D, Vicent S, Fraga MF, et al. Molecular analysis of a multistep lung cancer model induced by chronic inflammation reveals epigenetic regulation of $\mathrm{p} 16$ and activation of the DNA damage response pathway. Neoplasia. 2007;9(10):840-852.

119. O’Byrne KJ, Dalgleish AG. Chronic immune activation and inflammation as the cause of malignancy. Br J Cancer. 2001;85(4): $473-483$.

120. Oberdorster G, Gelein R, Johnston CJ, Mercer P, Corson N, Finkelstein JN. Ambient ultrafine particles: inducers of acute lung injury? In: Mohr U, Dungworth DL, Brain JD, Driscoll KE, Grafstrom RC, Harris CC, editors. Relationships between respiratory disease and exposure to air pollution. Washington: ILSI Press; 1998. pp. 216-229.

121. Li XY, Gilmour PS, Donaldson K, MacNee W. Free radical activity and pro-inflammatory effects of particulate air pollution (PM10) in vivo and in vitro. Thorax. 1996;51(12):1216-1222.

122. Gojova A, Guo B, Kota RS, Rutledge JC, Kennedy IM, Barakat AI. Induction of inflammation in vascular endothelial cells by metal oxide nanoparticles: effect of particle composition. Environ Health Perspect. 2007;115(3):403-409.

123. Peters K, Unger RE, Kirkpatrick CJ, Gatti AM, Monari E. Effects of nano-scaled particles on endothelial cell function in vitro: studies on viability, proliferation and inflammation. J Mater Sci Mater Med. 2004;15(4):321-325.

124. Lane DP. Cancer. p53, guardian of the genome. Nature. 1992; 358(6381):15-16.

125. George S, Pokhrel S, Xia T, et al. Use of a rapid cytotoxicity screening approach to engineer a safer zinc oxide nanoparticle through iron doping. ACS Nano. 2010;4(1):15-29.

126. Fujita K, Morimoto Y, Ogami A, et al. Gene expression profiles in rat lung after inhalation exposure to $\mathrm{C} 60$ fullerene particles. Toxicology. 2009;258(1):47-55.

127. Liu X, Sun J. Endothelial cells dysfunction induced by silica nanoparticles through oxidative stress via JNK/P53 and NF-kappaB pathways. Biomaterials. 2010;31(32):8198-8209.

128. Xia T, Kovochich M, Brant J, et al. Comparison of the abilities of ambient and manufactured nanoparticles to induce cellular toxicity according to an oxidative stress paradigm. Nano Lett. 2006;6(8): 1794-1807.

129. Mossman BT, Bignon J, Corn M, Seaton A, Gee JB. Asbestos: scientific developments and implications for public policy. Science. 1990;247(4940):294-301.

130. Mossman BT, Churg A. Mechanisms in the pathogenesis of asbestosis and silicosis. Am J Respir Crit Care Med. 1998;157(5 Pt 1): 1666-1680.

131. Robinson BW, Lake RA. Advances in malignant mesothelioma. N Engl J Med. 2005;353(15):1591-1603.

132. Mossman BT, Gee JB. Asbestos-related diseases. $N$ Engl J Med. 1989;320(26):1721-1730. 
133. Guthrie GD Jr, Mossman BT. Health effects of mineral dusts. Washington, DC: Mineralogical Society of America; 1993: 28.

134. Heintz NH, Janssen-Heininger YM, Mossman BT. Asbestos, lung cancers, and mesotheliomas: from molecular approaches to targeting tumor survival pathways. Am J Respir Cell Mol Biol. 2010;42(2):133-139.

135. Toyokuni S. Mechanisms of asbestos-induced carcinogenesis. Nagoya J Med Sci. 2009;71(1-2):1-10.

136. Magnani C, Agudo A, Gonzalez CA, et al. Multicentric study on malignant pleural mesothelioma and non-occupational exposure to asbestos. Br J Cancer. 2000;83(1):104-111.

137. Senyigit A, Bayram H, Babayigit C, et al. Malignant pleural mesothelioma caused by environmental exposure to asbestos in the southeast of Turkey: CT findings in 117 patients. Respiration. 2000;67(6): 615-622.

138. Biomarkers Definitions Working Group. Biomarkers and surrogate endpoints: preferred definitions and conceptual framework. Clin Pharmacol Ther. 2001;69(3):89-95.

139. Xia T, Li N, Nel AE. Potential health impact of nanoparticles. Annu Rev Public Health. 2009;30:137-150.

140. Luo JC, Hsu KH, Shen WS. Inflammatory responses and oxidative stress from metal fume exposure in automobile welders. $J$ Occup Environ Med. 2009;51(1):95-103.

141. Antonini JM, Stone S, Roberts JR, et al. Effect of short-term stainless steel welding fume inhalation exposure on lung inflammation, injury, and defense responses in rats. Toxicol Appl Pharmacol. 2007;223(3):234-245.

142. Bydash J, Kasmani R, Naraharisetty K. Metal fume-induced diffuse alveolar damage. J Thorac Imaging. 2010;25(2):W27-W29.

143. Cooper RG. Zinc toxicology following particulate inhalation. Indian J Occup Environ Med. 2008;12(1):10-13.

144. Xiao GG, Wang M, Li N, Loo JA, Nel AE. Use of proteomics to demonstrate a hierarchical oxidative stress response to diesel exhaust particle chemicals in a macrophage cell line. J Biol Chem. 2003;278(50): 50781-50790.

145. Wang M, Xiao GG, Li N, Xie Y, Loo JA, Nel AE. Use of a fluorescent phosphoprotein dye to characterize oxidative stress-induced signaling pathway components in macrophage and epithelial cultures exposed to diesel exhaust particle chemicals. Electrophoresis. 2005;26(11):2092-2108.

146. Jung EJ, Avliyakulov NK, Boontheung P, Loo JA, Nel AE. Pro-oxidative DEP chemicals induce heat shock proteins and an unfolding protein response in a bronchial epithelial cell line as determined by DIGE analysis. Proteomics. 2007;7(21):3906-3918.

147. Zhang L, Wang M, Kang X, et al. Oxidative stress and asthma: proteome analysis of chitinase-like proteins and FIZZ1 in lung tissue and bronchoalveolar lavage fluid. J Proteome Res. 2009;8(4):1631-1638.

148. Kang X, Li N, Wang M, et al. Adjuvant effects of ambient particulate matter monitored by proteomics of bronchoalveolar lavage fluid. Proteomics. 2010;10(3):520-531.

149. Li N, Wang M, Bramble LA, et al. The adjuvant effect of ambient particulate matter is closely reflected by the particulate oxidant potential. Environ Health Perspect. 2009;117(7):1116-1123.

150. Li N, Harkema JR, Lewandowski RP, et al. Ambient ultrafine particles provide a strong adjuvant effect in the secondary immune response: implication for traffic-related asthma flares. Am J Physiol Lung Cell Mol Physiol. 2010;299(3):L374-L383.

151. Ohshima H, Tazawa H, Sylla BS, Sawa T. Prevention of human cancer by modulation of chronic inflammatory processes. Mutat Res.2005;591(1-2):110-122.

152. Baggs RB, Ferin J, Oberdorster G. Regression of pulmonary lesions produced by inhaled titanium dioxide in rats. Vet Pathol. 1997;34(6): 592-597.

153. Oberdorster G. Pulmonary effects of inhaled ultrafine particles. Int Arch Occup Environ Health. 2001;74(1):1-8.

154. Wang B, Feng WY, Wang TC, et al. Acute toxicity of nano- and microscale zinc powder in healthy adult mice. Toxicol Lett. 2006;161(2): $115-123$.
155. Muller J, Huaux F, Fonseca A, et al. Structural defects play a major role in the acute lung toxicity of multiwall carbon nanotubes: toxicological aspects. Chem Res Toxicol. 2008;21(9):1698-1705.

156. Chithrani BD, Chan WC. Elucidating the mechanism of cellular uptake and removal of protein-coated gold nanoparticles of different sizes and shapes. Nano Lett. 2007;7(6):1542-1550.

157. Gratton SE, Ropp PA, Pohlhaus PD, et al. The effect of particle design on cellular internalization pathways. Proc Natl Acad Sci U SA. 2008;105(33):11613-11618.

158. Pacurari M, Yin XJ, Zhao J, et al. Raw single-wall carbon nanotubes induce oxidative stress and activate MAPKs, AP-1, NF-kappaB, and Akt in normal and malignant human mesothelial cells. Environ Health Perspect. 2008;116(9):1211-1217.

159. Maples KR, Johnson NF. Fiber-induced hydroxyl radical formation: correlation with mesothelioma induction in rats and humans. Carcinogenesis. 1992;13(11):2035-2039.

160. Donaldson K, Beswick PH, Gilmour PS. Free radical activity associated with the surface of particles: a unifying factor in determining biological activity? Toxicol Lett. 1996;88(1-3):293-298.

161. Ghio AJ, Stonehuerner J, Dailey LA, Carter JD. Metals associated with both the water-soluble and insoluble fractions of an ambient air pollution particle catalyze an oxidative stress. Inhal Toxicol. 1999;11(1):37-49.

162. Kagan VE, Tyurina YY, Tyurin VA, et al. Direct and indirect effects of single walled carbon nanotubes on RAW 264.7 macrophages: role of iron. Toxicol Lett. 2006;165(1):88-100.

163. Lam CW, James JT, McCluskey R, Hunter RL. Pulmonary toxicity of single-wall carbon nanotubes in mice 7 and 90 days after intratracheal instillation. Toxicol Sci. 2004;77(1):126-134.

164. Wick P, Manser P, Limbach LK, et al. The degree and kind of agglomeration affect carbon nanotube cytotoxicity. Toxicol Lett. 2007;168(2): 121-131.

165. Fubini B, Ghiazza M, Fenoglio I. Physico-chemical features of engineered nanoparticles relevant to their toxicity. Nanotoxicology. 2010;4(4):347-363.

166. Maynard AD, Baron PA, Foley M, Shvedova AA, Kisin ER, Castranova V. Exposure to carbon nanotube material: aerosol release during the handling of unrefined single-walled carbon nanotube material. $J$ Toxicol Environ Health A. 2004;67(1):87-107.

167. Shvedova AA, Kisin ER, Mercer R, et al. Unusual inflammatory and fibrogenic pulmonary responses to single-walled carbon nanotubes in mice. Am J Physiol Lung Cell Mol Physiol. 2005;289(5):L698-L708.

168. Thess A, Lee R, Nikolaev P, et al. Crystalline ropes of metallic carbon nanotubes. Science. 1996;273(5274):483-487.

169. Kim YH, Park HW, Ryoo ZY, Lee HS, Kim DH, Lee S. Abnormal effects of unpurified and purified multi-walled carbon nanotubes in A549, Jurkat and THP-1 cell lines. Mol Cell Toxicol. 2012;8(1): 103-112.

170. Chandra S, Barick KC, Bahadur D. Oxide and hybrid nanostructures for therapeutic applications. Adv Drug Deliv Rev. 2011;63(14-15) $1267-1281$.

171. Magdolenova Z, Bilanicova D, Pojana G, et al. Impact of agglomeration and different dispersions of titanium dioxide nanoparticles on the human related in vitro cytotoxicity and genotoxicity. J Environ Monit. 2012;14(2):455-464.

172. Fu YS, Du XW, Kulinich SA, et al. Stable aqueous dispersion of $\mathrm{ZnO}$ quantum dots with strong blue emission via simple solution route. J Am Chem Soc. 2007;129(51):16029-16033.

173. Munnier E, Cohen-Jonathan S, Linassier C, et al. Novel method of doxorubicin-SPION reversible association for magnetic drug targeting. Int J Pharm. 2008;363(1-2):170-176.

174. Valois CR, Braz JM, Nunes ES, et al. The effect of DMSA-functionalized magnetic nanoparticles on transendothelial migration of monocytes in the murine lung via a beta2 integrin-dependent pathway. Biomaterials. 2010;31(2):366-374.

175. Maurizi L, Bisht H, Bouyer F, Millot N. Easy route to functionalize iron oxide nanoparticles via long-term stable thiol groups. Langmuir. 2009;25(16):8857-8859. 
176. Lim JK, Majetich SA, Tilton RD. Stabilization of superparamagnetic iron oxide core-gold shell nanoparticles in high ionic strength media. Langmuir. 2009;25(23):13384-13393.

177. Xie J, Xu C, Kohelr N, Hou Y, Sun S. Controlled PEGylation of monodisperse $\mathrm{Fe} 3 \mathrm{O} 4$ nanoparticles for reduced non-specific uptake by macrophage cells. Adv Mater. 2007;19(20):3163-3166.

178. Soenen SJH, Hodenius M, Schmitz-Rode T, De Cuyper M. Protein-stabilized magnetic fluids. J Magn Magn Mater. 2008; 320(5):634-641.

179. Nasongkla N, Bey E, Ren J, et al. Multifunctional polymeric micelles as cancer-targeted, MRI-ultrasensitive drug delivery systems. Nano Lett. 2006;6(11):2427-2430.

180. Pradhan P, Giri J, Rieken F, et al. Targeted temperature sensitive magnetic liposomes for thermo-chemotherapy. $J$ Control Release. 2010;142(1):108-121.

181. Sayes CM, Liang F, Hudson JL, et al. Functionalization density dependence of single-walled carbon nanotubes cytotoxicity in vitro. Toxicol Lett. 2006;161(2):135-142.

182. Singh R, Pantarotto D, Lacerda L, et al. Tissue biodistribution and blood clearance rates of intravenously administered carbon nanotube radiotracers. Proc Natl Acad Sci US A. 2006;103(9): 3357-3362.

183. Chen P, Kuo CW, Lai JJL. Cytotoxicity of the functionalized gold and silver nanorods. Mat Res Soc. 2007;951:105-110.

184. Yim WC, Lee B-M, Kwon Y. Cross-experimental analysis of microarray gene expression datasets for in silico risk assessment of $\mathrm{TiO} 2$ nano-particles. Mol Cell Toxicol. 2012;8(3):229-239.
185. Park S-K, Kim J-J, Yu A-R, Lee M-Y, Park S-K. Electrolyzedreduced water confers increased resistance to environmental stresses. Mol Cell Toxicol. 2012;8(3):241-247.

186. Jiang J, Oberdörster G, Biswas P. Characterisation of size, surface charge and agglomeration state of nanoparticle dispersions for toxicological studies. J Nanopart Res. 2009;11:77-89.

187. Harush-Frenkel O, Debotton N, Benita S, Altschuler Y. Targeting of nanoparticles to the clathrin-mediated endocytic pathway. Biochem Biophys Res Commun. 2007;353(1):26-32.

188. Lockman PR, Koziara JM, Mumper RJ, Allen DD. Nanoparticle surface charges alter blood-brain barrier integrity and permeability. J Drug Target. 2004;12(9-10):635-641.

189. Nan A, Bai X, Son SJ, Lee SB, Ghandehari H. Cellular uptake and cytotoxicity of silica nanotubes. Nano Lett. 2008;8(8):2150-2154.

190. Clift MJ, Rothen-Rutishauser B, Brown DM, et al. The impact of different nanoparticle surface chemistry and size on uptake and toxicity in a murine macrophage cell line. Toxicol Appl Pharmacol. 2008;232(3):418-427.

191. Gonzalez L, Lison D, Kirsch-Volders M. Genotoxicity of engineered nanomaterials:a critical review. Nanotoxicology. 2008;2:252-273.

192. Landsiedel R, Kapp MD, Schulz M, Wiench K, Oesch F. Gentoxicity investigations on nanomaterials: methods, preparation and characterization of test material, potential artifacts and limitations- many questions, some answers. Mutat Res. 2009;681:241-258.
International Journal of Nanomedicine

\section{Publish your work in this journal}

The International Journal of Nanomedicine is an international, peerreviewed journal focusing on the application of nanotechnology in diagnostics, therapeutics, and drug delivery systems throughout the biomedical field. This journal is indexed on PubMed Central, MedLine, CAS, SciSearch ${ }^{\circledR}$, Current Contents ${ }^{\circledR} /$ Clinical Medicine,

\section{Dovepress}

Journal Citation Reports/Science Edition, EMBase, Scopus and the Elsevier Bibliographic databases. The manuscript management system is completely online and includes a very quick and fair peer-review system, which is all easy to use. Visit http://www.dovepress.com/ testimonials.php to read real quotes from published authors. 